\title{
Ta'dibuna
}

Jurnal Pendidikan Islam

Vol. 6, No. 2, Oktober 2017, p-ISSN: 2252-5793, hlm. 136-114

\section{Pesantren Salafiyah dan ResPonnya di Era GlobalisaSi}

\author{
Hasbi Indra \\ Universitas Ibn Khaldun Bogor
}

\begin{abstract}
Penelitian ini bersifat kualitatif yang bersumber pada pemikiran para ahli melalui buku, jurnal dan lainnya melalui pendekatan normatif, filosofis dan sosiologis. Penelitian ini hendak menggambarkan bagaimana pesantren yang memiliki santri 1.800 .00 lebih menyiapkan diri di era globalisasi yang penuh dinamika dan tantangan. Pesantren salafiyah lahir di era Walisongo di masa penjajahan Belnda. Lembaga ini didirikan oleh masyarakat yang saat ini sudah menyebar ke seluruh pelosok Indonesia. Dari jumlah santri 29.000 dari jenis kombinasi, modern dan salafiyah, jumlah 18.232 pesantren salafiyah dengan santri 1.8 juta lebih dari 3.800.000 lebih. Di pesantren ini santri hanya belajar ilmu agama melalui kitab-kitab ulama klasik (kitab kuning) tidak mempelajari sains seperti MIFA. Pesantren ini sedang menghadapi fenomena globalisasi. Globalisasi ditandai oleh hubungan manusia yang tidak terbatas, melalui faksimil,, manusia mendapat informasi dari tempat yang sangat jauh baik informasi yang menyedihkan seperti perang tentara amerika dengan tentara Irak serta tentara ISIS yang membumihanguskan peninggalan bersejrah masa keemasan Islam. Majunya teknologi di era globalisasi menjadi tantangan pendidikan pesantren. Produks pesantren salafiyah harus menyiapkan dirinya dengan ilmu agama, non agama dan skill dan sudah mengenal alat-alat teknologi pembelajaran di pendidikannya, dengan demikian santrinya siap berkompetsi di era globalisasi ini, untuk itu lembaga ini harus dikelola secara profesional.
\end{abstract}

Kata kunci: Pesantren Salafiyah, Globalisasi, IPTEK

\section{Pendahuluan}

Pesantren sebagai lembaga pendidikan Islam lahir di era penjajahan di masa penyebaran Islam di Nusantara yakni di era Walisongo (Indra, 2016). Semula pendidikan Islam masih dalam skala kecil yang diselenggarakan di rumah atau masjid tetapi karena di dua tempat itu memiliki keterbatasan, sementara peserta didik semakin banyak dan berdatangan dari tempat yang jauh, maka lembaga ini mengalami perkembangan di mana penyelenggaraan pendidikannya di suatu bangunan. Bangunan itu di samping tempat belajar agama juga ada bangunan tempat tinggal bagi para santri yang mukim, bangunan ini berada di lingkungan masjid, pendidikan ini kemudian disebut dengan pondok pesantren. 
Pondok pesantren di era penjajahan di samping untuk belajar ilmu agama juga tempat menggugah semangat santri untuk melawan dan mengusir penjajah dari Nusantara melalui doktrin Al-quran dan Al-hadits. Pendidikan pesantren yang semula berdiri di pulau Jawa berkembang ke luar Jawa, dari daerah pedesaan berkembang ke perkotaan. Kemudian ia mengalami perkembangan dari bentuknya Salafiyah berkembang berbentuk kombinasi dan berbentuk modern.

Pendidikan ini sebagai tempat mencerdaskan anak bangsa dan menyiapkan mereka mengisi pembangunan Indonesia. Sebagai lembaga pendidikan ia telah berlangsung dari masa ke masa sejak masa penjajahan, era Orde Lama Orde Baru, dan era Reformasi. Setiap era lembaga ini menghadapi tantangannya tersendiri. Begitu pula era globalisasi di mana santri pesantren salafiyah harus hadir dan harus siap menghadapinya. Era ini dinamika kehidupan manusia demikian cepat yang ditandai oleh kemajuan ilmu pengetahuan dan teknologi, yang memudahkan manusia menyerap informasi dalam waktu hitungan detik atau menit dari tempat yang sangat jauh melalui alat komunikasi seperti TV dan manusia hidupnya tidak lepas dengan alat teknologi tersebut. Maka untuk itu, Pesantren Salafiyah harus menyiapkan anak didiknya memiliki wawasan bukan saja ilmu agama tetapi juga wawasan keilmuan yang lebih luas, untuk melakukan perannya di masyarakat yang mereka juga bersentuhan atau bergelut dengan ilmu dan teknologi, maka lulusannya harus hadir dengan wawasan dan perangkat-perangkat tersebut, sehingga peran lulusannya di tengah masyarakat berlangsung secara optimal.

Pendidikan pesantren yang kiprahnya sejak masa penjajahan hingga kini di era globalisasi, kiprahnya semakin terasa apabila ia menyesuaikan dirinya dengan tuntutan zaman dan santrinya eksis di tengah masyarakat. Tulisan ini berdasarkan penelitian kualitatif yang bersumber pada pemikiran para ahli melalui buku, jurnal dan lainya yang menggunakan analisis descriptif melalui pendekatan noramatif, filosofis dan sosiologis (Moleong, 2001; Nata, 1999), dan mencoba memberikan gambaran bagaimana seharusnya Pesantren Salafiyah yang memiliki santri 1. 800.000 lebih, jumlah yang sangat signifikan sebagai sumber daya bangsa ke depan dengan menyiapkan dirinya mengahadapi tantangan globalisasi yang tidak bisa dihindari oleh pendidikan tersebut.

\section{Pesantren dan Perkembangannya}

Pesantren adalah lembaga pendidikan Islam di Indonesia yang hampir seluruhnya didirikan oleh masyarakat, semakin eksis hingga hari ini. Lembaga pendidikan Islam yang sekarang disebut dengan pesantren didirikan bersamaan dengan penyebaran Islam di masyarakat di mana sebagian besar penduduknya muslim. Pada era ini pendidikan Islam mendapat dukungan dari Sultan pada masa itu (Depag, 2000).

Pesantren adalah pendidikan original muslim di Nusantara. Hasbi menyebutkan bahwa pesantren sudah ada di masa Walisongo yang pertama kali didirikan oleh Raden Ahmad pada abad 16 di Gresik Jawa Timur (Indra, 2009b). Pesantren dari kata santri terdiri dua suku kata sant (orang baik) and tra untuk mencetak orang baik (Abdullah, 1983). 
Sementara itu Berg menyatakan kata santri berasal dari kata shastri atau shastra yang artinya seseorang yang memiliki pemahaman terhadap buku agama yang berkaitan dengan pengetahuan agama. Pesantren yang pertama kali muncul di pulau Jawa dan pada saat ini juga berkembang di luar pulau jawa. Zamakhsyari Dofier berpandangan pesantren memiliki 4 ciri yakni: ada masjid, ada kyai, santri dan kitab kuning sebagai sumber rujukan belajar ilmu agama (Dhofier, 1994).

Di pendidikan ini pada masa awal-awalnya santri belajar membaca Al-quran dari seorang ustadz yang bertempat di rumahnya, ada juga yang bertempat di masjid, kemudian materi belajarnya bertambah yakni belajar ilmu agama (Soejoeti, 2002). Tetapi santri yang belajar baik di rumah maupun di masjid lama kelamaan di dua tempat itu sudah merasa sudah sangat sempit, sang ustadz atau kyainya bersama umat disekitarnya mendirikan satu tempat sebagai tempat belajar. Apalagi perkembangan berikutnya santri belajar agama ke seorang kyai yang sudah kesohor memiliki banyak ilmu dan santrinya berasal dari tempat yang jauh dari kediaman kyai, maka sang kyai bersama umat disekitarnya secara bersama-sama membangun suatu tempat untuk para santri belajar dan tempat tinggal yang disebut dengan pesantren.

Di pesantren di samping tempat belajar al-quran dan ilmu agama juga sebagai tempat untuk membentuk karakter anak didik seperti hormat kepada orang lain, berdisiplin, jujur, mandiri dan sebagainya. Di tempat ini santri belajar setelah shalat subuh hingga jam 9 atau jam 10 malam hari, mereka belajar selama 16 jam. Umumnya mereka dilarang melihat TV dan mendengar radio. Karenanya mereka tidak terpengaruh dengan dunia luar moral mereka terbina menjadi baik di samping dikuatkan melalui kitab-kitab akhlak juga sering dicontohkan oleh kyai secara langsung sehingga menjadi kebiasaan bagi mereka.

Mereka bermental mandiri seperti mencuci sendiri pakaiannya yang kotor dan mengerjakan kebutuhan-kebutuhannya sendiri. Mental mereka sangat kokoh seperti pejuang dan tidak mengenal putus asa. Hanya saja belajar di pesantren tidak membentuk santri menjadi santri yang kreatif. Karena model pembelajarannya sedikit dialog dan ustazd mengajar hanya monolog. Padahal, sifat Allah adalah Maha Pencipta segala sesuatu di alam ini, karena itu manusia harus memiliki sifat itu seperti Allah menciptakan segala sesuatu di alam dunia (lihat QS, al-Imran, 3: 190; al-Mukminun, 23: 12-15).

Dalam belajar ilmu agama mereka di bawah asuhan kyai melalui kitab-kitan kuning seperti ilmu tauhid, fiqh, tafsir-hadits, akhlak dan gramatika bahasa Arab juga diajarkan ilmu mantiq, balaghah, faraidh dan lainnya (Indra, 2009b). Kitab-kitab kuning memiliki beberapa level, level awal, level menengah dan level tinggi sesuai dengan lamanya santri belajar di pesantren. Di pesantren mengenal beberapa model pembelajaran yakni di kenal model sorogan dimana setiap santri belajar langsung ke kyai, santri langsung mendengar bacaan dari kyai dan penjelasaannya. Model kedua yang dikenal bandongan model yakni para santri belajar ke kyai berkelompok, mereka mencatat penjelasan kyai di sisi kitab kuning atau memberi makna di bawah pragraf atau kalimat. Model ketiga 
dikenal halaqah bahwa para santri belajar berkelompok, mendiskusikan masalah dan mencari solusinya (Fatah, Taufik, \& Bisri, 2005).

Di era penjajahan, pesantren menjadi tempat perlawanan, kyai memberi semangat pada santri melalui ayat-ayat Al-quran untuk mengusir penjajah dari Nusantara. Karena penjajah melakukan penindasan atau penganiayaan pada umat Islam di Nusantara dengan panggilan jihad perang untuk mengusir mereka. Santri pada masa ini dibentuk memiliki semangat melawan penjajah dan mereka mencitakan dirinya menjadi syuhada (Indra, 2009b).

Di samping itu pada masa penjajahan ini telah tumbuh lembaga pendidikan yang dibangun pemerintahan kolonialisme yang tujuannya untuk menyiapkan kaum pribumi sebagai administrator pada pemerintahan penjajah. Siswanya belajarnya di kelas dan mereka belajar ilmu sekuler seperti berhitung, biologi, kimia dan lainnya yang sebenarnya ilmu-ilmu ini telah berkembang di masa Islam era Abbasiyah. Para gurunya adalah orang-orang profesional. Mereka melakukan evaluasi terhadap kemajuan belajar anak didik melalui evaluasi tengah semester dan akhir semester. Dari evaluasi ini pelajar yang dibawah standar dinyatakan tidak naik kelas dan mengulang di tahun berikutnya. Lulusannya memperoleh ijazah dan mereka dapat bekerja di pemerintahan dan diberi gaji yang cukup dan mereka memiliki sepeda dan rumah yang luas. Sistem pendidikan ala penjajah juga mempengaruhi dunia pendidikan pesantren terutama di mata pelajarannya, mereka tidak hanya belajar agama tetapi juga belajar ilmu berhitung dan ilmu sekuler lainnya, inilah awal adanya dinamika di pesantren (Azra, 1998).

Setelah era penjajahan pesantren semakin eksis dan semakin berkembang. Pesantren berkembang menjadi tiga bentuk: pertama, pesantren salafiyah yaitu pesantren yang fokus pada belajar agama bersumber pada kitab kuning. Tipe kedua, pesantren kombinasi yakni santri belajar ilmu agama di malam yang bersumber dari kitab kuning dan pagi harinya mereka belajar ilmu sekuler di sekolah formal di tingkat dasar atau menengah. Tipe ketiga, pesantren modern, santri hanya belajar ilmu agama melalui bacaan atau buku-buku Islam kontemporer dan kitab kuning hanya pilihan saja dan mereka harus berbicara dengan bahasa Inggris atau Arab di pesantren (Indra, 2002).

Melalui pendidikan ini para santrinya banyak bercita-cita menjadi pelayan dalam beragama dan juga bercita-cita menjadi politisi yang memiliki konsep untuk memperjuangkan Islam sebagai ideologi negara. Dalam konteks pesantren Salafiyah di Jawa ada juga yang berkembang dengan model pembelajaran kelas, dan melakukan evaluasi terhadap santrinya (Azra, 1998). Pesantren dalam bentuk ini juga mengalami perkembanan ada juga pesantren hanya sebagai tempat tinggal dan mereka belajar di luar pesantren di sekolah umum di pagi hari dan di malam hari mereka belajar agama dari kitab kuning (Azra, 1998). Pesantren terus mengalami perkembangan lebih lanjut di mana para memiliki kesempatan untuk memiliki skill seperti jahit-menjahit, pertukangan, koperasi dan sebagainya. Pesentren juga mengembangkan potensinya untuk menjadi pusat pengembangan masyarakat (Indra, 2002). Dengan potensi-potensi itu pesantren dapat memberikan pengalaman bagi para santrinya pada bidang perikanan, 
pertanian dan lainnya sebagai modal mereka setelah selesai dari pesantren mereka dapat memanfaatkan pengalamannya untuk memberdayakan masyarakat. Hanya saja pesantren model ini hanya bisa dihitung dengan jari atau masih sangat langka.

Pesantren semakin mendapat perhatian pemerintah dengan regulasinya melalui Peraturan Menteri Agama No. 12001 yang membuat struktur baru yang menangani pesantren pada unit eselon II di Departemen Agama. Kemudian melalui UU No. 20, 2003, dan Peraturan Pemerintah No. 55, 2007 telah menjadi bagian dari sistem pendidikan nasional. Pendidikan pesantren sebagai bagian dari sistem pendidikan nasional telah melibatkan dirinya dalam Program Wajib Belajar 9 tahun di beberapa Pesantren Salafiyah juga Program Paket tingkat A, B and C dan santri berkesempatan mempelajari pelajaran sekuler dan mereka mendapat ijazah dan mereka dapat bekerja di pemerintahan atau di sektor swasta atau menjadi pelayan kehidupan beragama dan pemimpin informal di masyarakat (Dinamika Pesantren di Indonesia, 2003).

Tuntutan dan dinamika masyarakat, pesantren dapat meresponnya melalui perubahan kebijakan dan menerapkan pengelolaan yang profesional. Pada dasarnya perubahan diperlukan dalam kehidupan ini dan perubahan itu akan terus menerus berlangsung sepanjang kehidupan manusia menuju ke penyempurnaan. Dengan kata lain lembaga pesantren memilihara nilai lama dan mengambil nilai-nilai baru yang baik.

Perubahan sosial sebagai akibat dari dampak globalisasi yang memunculkan tantangan-tantangan baru sesuatu yang tak terhindarkan. Pesantren sebagai institusi sosial telah berkontribusi penting dalam pengembangan spiritual muslim di mana masyarakat menuntut pemecahan terhadap berbagai problemnya. Hanya saja pengembangan pesantren yang terus berlangsung sayangnya hanya bersifat reaktif. Sesungguhnya perubahan yang baik memerlukan perencanaan dan kajian mendalam terhadap masalah-masalah yang dihadapi masyarakat di mana pesantren harus ikut mengatasinya.

Pesantren Salafiyah di era mendatang yang jumlah santrinya dalam kisaran 1.882.901 dari 3.876.696 untuk semua jenis pesantren; 18.232 dari 29.535 jumlah lembaga, dan 100.000 guru dari 160.000 (Pendis, 2014), jumlah yang sangat signifikan sebagai sumber daya bangsa Indonesia, harus menyiapkan diri menghadapi globalisasi. Semua santri memerlukan modal dengan pengetahuan keislamannya melalui kitab kuning, perlu mempelajari ilmu sekuler seperti matematika, sains dan skill sebagai modal kehidupannya.

\section{Pesantren Salafiyah dan Tantangannya}

Pesantren salafiyah yang jumlah satrinya 1.882 .901 (Pendis, 2014), mereka umumnya hanya belajar ilmu agama melalui kitab kuning dan tidak belajar ilmu sekuler, padahal mereka hidup di era keterbukaan saat ini. Mereka hidup bukan untuk dirinya sendiri tetapi harus bermanfaat bagi orang lain, karenanya mereka harus berintraksi dengan manusia lain. Mereka hidup di tengah kehidupan manusia yang serba cepat melalui alat komunikasi dengan hitungan neno second. Manusia hidup di tengah manusia 
yang menggunakan email dan hasil yang tercetak hanya dalam hitungan detik. Melalui televisi dapat dinikmati berbagai informasi yang juga dalam waktu yang sangat cepat. Amerika dan Sekutunya memerangi tentara Irak dan membunuh ribuan rakyatnya dan menghanguskan bangunan-bangunan bersejarah di Irak, terlihat pula bagaimana tentara Israel menembaki anak Palestina yang hanya bersenjatakan batu. Juga kita melihat tentara Islamic State Irak and Syria (ISIS) yang membumihanguskan fakta sejarah masa keemasaan Islam di Irak dan Syria. Dalam konteks ini Marshall McLutan berpandangan bahwa dunia bagaikan desa global (Ibrahim, 1995).

Kemajuan IPTEK yang luar biasa dicapai telah melalui seminar dalam bidang transportasi laut, udara dan darat(Indra, 2009a), juga bidang kedokteran, angkasa luar, bio-teknologi, energi dan material, berbagai teori muncul sudah mampu menerangkan beragam hukum alam, mulai dari hukum yang mengatur gerak orbit dan galaksi kemaharayaan alam semesta sampai yang menerangkan sifat-sifat sub atom.

Kemajuan-kemajuan di atas telah membawa perubahan-perubahan yang dahsyat dalam sejarah kehidupan umat manusia. Perubahan-perubahan yang mondial cakupannya instan kecepatannya dalam penetrasinya. Jarak menjadi nisbi, dan jagad pun terangkum dari ujung ke ujung. Inilah masa pertama dimana Barat bertatapan langsung dengan Timur dalam skala massif. Dalam kontak peradaban ini dibutuhkan kerjasama dan saling pengertian. Tidak hanya untuk survival tetapi untuk mendapatkan yang terbaik dari semua peradaban, semua adat istiadat, semua bidang kehidupan. Kearifan pun diperlukan agar dominasi dan hegomoni nilai terelakkan, sehingga kemajemukan dan heterogonitas dapat ditumbuhkan.

Saat ini konsep jarak antar satu kelompok masyarakat dengan masyarakat lain dalam suatu batas suatu wilayah negara seperti jarak antara planet dengan planet lainnya secara teknologi lewat sudah. Kini kesadaran baru manusia hadir sebagai penghuni planet. Manusia merasa berada dalam pesawat antariksa yang sama, yang bernama bumi. Di mana tidak ada yang berstatus penumpang tapi semuanya awak pesawat. Manusia menyadari keberadaannya di teater bumi, di mana tidak ada yang menjadi penonton tapi semua menjadi pelakon. Demikian terasa, betapa dominannya IPTEK dalam mewarnai kebudayaan suatu bangsa termasuk bangsa Indonesia di era globalisasi ini (Ibrahim, 1995).

Tentang globalisasi, salah satu pandangan yang dapat disimak adalah pandangan Akhbar Ahmad dan Hasting, la memberi arti bahwa globalisasi pada dasarnya mengacu pada perkembangan yang cepat di dalam teknologi komunikasi, transformasi, informasi yang dapat membawa bagian-bagian dunia yang jauh yang bisa dijangkau dengan mudah (Ahmad \& Donnan, 1994). Globalisasi merupakan kelanjutan saja dari modernisasi yang pada dasarnya berisi sekularisasi yang isinya merupakan kelanjutan dari misi modern dan posmodemisme yang semakin sekuler, semakin maju dan semakin menjauh dari agama (Mas'ud, 1999). Dari sisi lain, globalisasi adalah proses pengintegrasian ekonomi national kepada sistem ekonomi dunia berdasarkan keyakinan pada perdagangan bebas yang sesungguhnya telah dicanangkan sejak zaman kolonialisme. Para teori kritis sejak lama sudah meramalkan bahwa kapitalisme akan berkembang menuju kepada dominasi 
ekonomi, politik dan budaya berskala global setelah perjalanan panjang melalui era kolonialisme (Faqih, 2003). Demikian pula tentang isu demokratisasi pemerintahan, HAM dan terorisme telah menjadi isu sentral pula. Melalui penetrasi budaya Barat ke bagian dunia lain melalui berbagai alat teknologi canggih membentuk uniform ekonomi, politik dan budaya ala Barat, Berbagai kemajuan dalam bidang ilmu dan teknologi dengan segera dapat pula dijadikan diskursus seluruh kalangan ilmuan dunia yang dapat mensejahterakan, menenteramkan dan memudahkan umat manusia ataukah sebaliknya justru dapat menyengsarakan dan bahkan menghancurkan umat manusia di planet ini.

Demikian pula saat ini terujud liberalisme perdagangan (Furchan, 2004). Hal itu telah dimulai sejak perjanjian internasional perdagangan yang dikenal dengan GATT. GATT merupakan suatu kumpulan aturan internasional yang mengatur perilaku perdagangan antar pemerintah serta juga merupakan pengadilan jika terjadi perselisihan dagang antar bangsa bisa diselesaikan. Kemudian tahun 1995 berdiri suatu organisasi pengawasan perdagangan dan kontrol perdagangan dunia yang dikenal dengan WTO sejak itu ia mengambil alih fungsi GATT. Selain itu di ringkat regional forum serupa untuk menetapkan kebijakan perdagangan juga ditetapkan seperti NAFTA antara Amerika dengan Maksiko, dan Sijori antara Singapura, Johor dan Riau Indonesia (Faqih, 2006).

Terjadinya liberalisme, atau lebih khusus lagi liberalisasi perdagangan, tidak dapat lepas dari kapitalisme dan pasar bebas. Kapitalisme ini adalah sistem ekonominya. Intinya adalah bahwa ekonomi itu urusan individu bukan pemerintah. Setiap individu bebas untuk mendapatkan keuntungan dalam mempraktikkan ekonomi. Intervensi pemerintah terhadap individu sangat dibatasi bahkan harus dihindari. Memang, perebutan keuntungan dapat menimbulkan persaingan yang sangat keras dan dapat diperbolehkan untuk saling menjatuhkan lewat iklan bebasnya (Ibrahim, 1995). Hal yang penting pula dalam praktik ekonomi kapitalime adalah tidak adanya larangan monopoli. Namun di sini ketentuan hukum dan penerapannya sangat ketat pula, sehingga jika menurut hukum ada yang dianggap merugikan atau dianggap menyalahi akan dengan mudah berhadapan dengan hukum dan akan mudah pula untuk dikenai sanksi atau denda yang tidak tanggung-tanggung. Oleh karena itu, persaingan bebas ini tidak berarti persaingan seperti di dalam hutan belantara. Dalam praktiknya, dengan adanya persaingan tersebut, akan terjadi kompetisi yang dianggap sehat (fair play). Konsekuensinya adalah menjadikan peredaran dan kegiatan ekonomi dan pasar menjadi dinamis dan keuntungan bagi masyarakat menjadi semakin jelas. Pada akhirnya, partumbuhan ekonomi negara menjadi semakin tinggi, serta kemakmuran akan bisa dinikmati oleh rakyat. Namun demikian, ekses sistem ini juga besar sekali, yaitu terjadinya jurang ( $\mathrm{gap}$ ) yang semakin curam antara si kaya dan si miskin. Meskipun dalam kenyataanya pula, si miskin tetap mempunyai ruang gerak atau kesempatan, tidak dijerat monopoli oleh pemerintah, untuk bangkit menjadi kuat dan kaya. Globalisasi bidang IPTEK ini telah menggapai seluruh dunia dan telah dirasakan manfaatnya sekaligus mudaratnya.

Bagi masyarakat yang berpandangan optimistik, kemajuan IPTEK memiliki manfaat yang besar terhadap umat manusia, dengan IPTEK masyarakat sangat terbantu dan lebih 
mudah dalam memenuhi kebutuhan hidupnya (sandang, pangan, papan, fasilitas belajar, berobat dan sebagainya). Namun, bagi yang berpandangan pesimistik melihat bahwa dengan IPTEK manusia kian terjebak dalam "kiamat" yang dihasilkan oleh tangan mereka sendiri. Ozon menjadi belong, air tercemar limbah industri, kesenjangan antara yang kaya dan yang miskin kian menganga, tindak kriminal kian sadis, nuklir mengancam (Indra, 2009a).

Kedua pandangan itu ada benarnya, karena di dunia ini pasti mengandung unsur positif dan negatif. Masalahnya strategi pengembangan IPTEK yang bagaimana yang dapat dikembangkan agar membawa manfaat positif bagi kehidupan budaya masyarakat, Menurut Marwah Daud, ada enam hal yang harus diperhatikan. Pertama, kebijakan IPTEK harus bersifat integratif dengan kebijakan nasional, IPTEK hanyalah salah satu bagian saja dari kebijakan pembangunan bangsa. Kedua, untuk mengembangkan Indonesia dlperlukan strategi pengembangan IPTEK yang terpadu dan menyeluruh, karena IPTEK dapat membantu rekayasa pembangunan bangsa yang terpadu dan menyeluruh. Ketiga, masalah IPTEK bukan saja berdimensi nasional tetapi juga berdimensi internasional, maka dlperlukan penanganan yang runtut. Keempat, dengan IPTEK telah memunculkan keragaman. Kelima, IPTEK dapat memunculkan konflik, namun dengan beragamnya akan memunculkan sintesis kreatif, dan keenam, memerlukan sikap dasar bahwa kita bukan hanya bersikap reaktif saja tetapi juga harus proaktif (Ibrahim, 1995).

Dalam rangka menghadapi globalisasi yang merupakan kelanjutan dari modernisasi, Nurcholis Madjid ketika mengomentari modenisasi, ia menyatakan bahwa hal itu merupakan keharusan dan tidak bisa dihindari, Islam sebenarnya sangat sesuai dengan modernisasi itu dengan ayat-ayat al-Qur'an, $7: 54 ; 25: 2,32: 7 ; 40: 3 ; 10: 101 ; 35$ : I3.

Umat Islam di era globalisasi ini hidup di arena kompetisi. Kompetisi sering ditandai oleh konsumerisme. Ini memerlukan landasan sehingga mampu menjadi perisai diri menghadapi kompetisi konsumerisme dan mampu pula menghadapi kehidupan yang wajar bahkan juga sesuai dengan nilai-nilai budaya dan agama. Contohnya yang ekstrim adalah adanya kebebasan berlebihan termasuk kebebasan seks dan kebebasan kehidupan negatif yang lain. Maka disini perisai mentalitas menjadi sangat penting. Dalam waktu yang bersamaan, kompetisi juga berkaitan dengan kemampuan dan prestasi. Kalau sebelum globalisasi, kompetisi belum sangat mengemuka maka pada era ini kompetisi sangat menonjol bukan hanya taraf lokal tetapi juga taraf antar negara. Kalau selama ini sebuah negara akan dengan mudah membuat aturan main sehingga dapat dijadikan perisai untuk mencegah serangan kompetisi dari luar maka kini sudah tidak dapat lagi. Kalau dulu Sumber Daya Manusia (SDM) yang hebat dapat dibatasi kini tidak dapat lagi.

Oleh karena itu, dalam menghadapi kompetisi seperti ini umat Islam perlu mempersiapkan diri. Mempersiapkan mental dalam kompetisi dan dalam waktu yang bersamaan mempersiapkan kemampuan SDM sehingga mampu berkompetisi, ini akan meliputi segala aspek kehidupan dalam hal perdagangan, pelayanan atau jasa dan lainnya. Komperisi juga membutuhkan rasa percaya diri (self confidence). Tentu saja 
sikap konfiden serta kaitannya dengan sikap individualisme (bukan egoisme). Oleh karena itu, wajar kalau kehidupan di dunia Barat yang liberal meliputi sistem ekonomi dan pola hidup harus dilandasi kepribadian yang individualis agar kira tidak terjebak ketika kita mengartikan individualisme, maka kita harus selalu ingat bahwa istilah ini tidak identik dengan egoisme dan selfness. Ketika seseorang harus berhadapan dengan dunia kompetisi, maka ia harus membuat fondasi yang kuat tentang self-confidence. Skill dan profesi apapun yang dimiliki seseorang tanpa fondasi self' confidence tidak akan mampu berkompetisi.

Untuk mewujudkan hal itu dalam berkompetisi, seseorang harus memenuhi dirinya sendiri dengan beberapa modal, bukan hanya perasaan saja. Di samping modal pengetahuan, modal mentalitas juga diperlukan. Etos kerja keras yang berorientasi pada prestasi, kedisiplinan, ketabahan tanpa mudah menyerah bahkan juga mentalitas kewirausahaan adalah hal-hal yang diperlukan dalam kerangka kompetisi dalam dunia perdagangan bebas (Indra, 2009a).

Selain itu diperlukan pula beberapa landasan yakni landasan spiritual dengan keimanan, untuk menghindarkan seseorang dari kekosongan jiwa menghadapi kompetisi konsumerisme. Wujud prestasi berupa amal shaleh, hal ini diperoleh setelah melakukan kerjakeras, kedisiplinan dan prestasi, kemudian berada pada kebenaran, artinya berada pada frame work, selalu mempunyai landasan hukum yang kuat serta pelaksanaan hukum yang mapan. Perlunya chek and balance, saling mengkritik yang konstruktif dan saling memberi informasi dan saling mengingatkan.

\section{Pesantren Salafiyah dan Responnya di Era Globalisasi}

Santri yang kini hidup di masyarakat global, dari sudut teknologi dapat dibagi menjadi tiga yaitu (1) kelompok technological innovator, mencakup hanya 15 persen dari seluruh penduduk dunia, tetapi menguasai seluruh inovasi teknologi yang terdapat di dunia ini, (2) kelompok technological adopters, mencakup kira-kira setengah dari penduduk dunia yatu kelompok bangsa-bangsa yang mampu menguasai teknologiteknologi baru hasil inovasi, terutama teknologi baru di bidang produksi serta komunikasi, dan (3) kelompok technologically exclude, mencakup kira-kira sepertiga dari penduduk dunia ini, yaitu kelompok penduduk dunia yang tidak mampu memperbaharui teknologi tradisional mereka dan tidak mampu pula menguasai inovasi-inovasi yang dihasilkan oleh masyarakat di luar wilayah mereka (Hamdy, 2004).

Wilayah yang termasuk ke dalam katagori technologically exclude ini tidak selalu berupa suatu negara atau bangsa, kebanyakan berupa kantong-kantong dalam suatu negara. Negara-negara yang tidak mampu mengikuti dinamika teknologi global pada umumnya berangsur-angsur mengalami kemunduran dan keterasingan dan akhirnya lumpuh. Ini disebabkan ekspor mereka yang berupa komoditas primer seperti pertanian, perkebunan, kehutanan dan hasil-hasil pertambangan sedikit demi sedikit digusur oleh produks-produks sintetis. Di samping itu, persoalan-persoalan demografis juga turut memperburuk keadaan negara-negara yang tidak mampu mengikuti dinamika teknologi 
global ini. Negara-negara golongan ini memerlukan serangkaian reformasi melalui pendidikan.

Di Indonesia kalau diperhatikan secara lebih mikro, akan diketahui banyak wilayah yang merupakan kantong-kantong dari keterkucilan teknologi (pockets of technologically exclude areas). Dalam dunia pendidikan lebih terasa di lingkungan pondok pesantren Salafiyah dikarenakan lokasi dan lingkungannya yang umumnya bersifat terkucil secara teknologis. Kalau ini terus berlangsung tentu mereka akan berada dalam keterbenaman dalam kemiskinan materiil yang berlangsung selama ini. Kita akan semakin bergantung pada golongan penduduk yang berkecukupan secara meteriil yang jumlahnya sungguh tidak banyak dalam menyelesaikan masalah-masalah mendesak yang dihadapi bangsa. Tentu saja ini merupakan situasi yang tidak sehat.

Salah satu upaya yang harus dilakukan adalah memberikan pendidikan MIPA di pesantren salafiyah. Masalahnya bagaimana cara mengatasi ketakutan serta kecurigaan terhadap matematika dan ilmu pengetahuan alam yang dibiarkan tumbuh dalam masyarakat dari generasi ke generasi memerlukan peninjauan ulang yang mendasar terhadap kehidupan budaya dan keagaman kita. Untuk seorang anak yang dibesarkan dalam keluarga santri tradisional, kata "hukum alam" akan membuatnya terkejut katena yang didengarnya setiap hari selama ini adalah "hukum Tuhan" (Indra, 2009b). Bagaimana mungkin bahwa alam yang merupakan ciptaan Tuhan mempunyai hukumnya sendiri? Masih banyak lagi prasangka-prasangka yang harus diatasi untuk membuat pendidikan MIPA diterima dengan hati terbuka dan minat yang cukup besar oleh setiap anggota dan setiap generasi baru.

Kalau kita betul-betul ingin meningkatkan kemampuan bangsa di bidang teknologi di masa depan, tidak boleh dibiarkan adanya anak-anak muda yang buta matematika dan buta ilmu pengetahuan alam. Memang benar tidak semua santri akan berminat menjadi ahli matematika, ahli ilmu pengetahuan alam atau ahli teknologi. Akan tetapi suatu masyarakat hanya akan berhasil mengembangkan kemampuan teknologi yang cukup tinggi kalau dalam masyarakat tadi terdapat lapisan-lapisan penduduk dengan tingkat pemahaman tentang matematika dan ilmu pengetahuan alam yang beragam, dari kemampuan yang bersifat ekspertise sampai ke pemahaman yang bersifat apresiatif (Hamdy, 2004).

Pada dasarnya setiap negara atau masyarakat yang ingin mengalami revolusi ilmiah yaitu loncatan raksasa dalam penguasaan matematika dan ilmu pengetahuan alam harus mampu mengembangkan empat lapisan penduduk dengan penguasaan yang berbedabeda tentang matematika dan ilmu pengetahuan alam ini. Paling atas adalah lapisan alpha-plus scientists, yaitu ilmuan dengan kemampuan yang sangat tinggi. Jumlah kelompok ini pada bangsa manapun tidak pernah besar. Pada lapisan kedua terdapat kelompok alpha professions yang jumlahnya jauh lebih besar daripada kelompok pertama tadi. Tugas kelompok kedua ini adalah melakukan supporting researche the high class design and development. Pada lapisan ketiga, terdapat ilmuan yang akan melakukan secondary technical jobs. Pada lapisan keempat adalah para politisi, birokrat dan 
masyarakat umum dengan pemahaman tentang matematika dan ilmu pengetahuan alam yang memadai sehingga mereka itu mengerti apa yang dibicarakan para ilmuan.

Oleh karena itu, pengetahuan matematika dan ilmu pengetahuan alam harus dimiliki oleh seluruh lapisan penduduk. Mereka yang tidak mempunyai keinginan untuk menjadi ahli matematika atau ahli ilmu pengetahuan alam pun perlu tahu apa matematika dan ilmu pengetahuan alam itu. Inilah mengapa para santri tidak boleh dibiarkan menjadi buta matematika dan ilmu pengtahuan alam.

Alasan yang bersifat sosio-kultural harus ditangani. Kebutaan terhadap matematika yang dibiarkan melembaga, artinya dibiarkan menjadi suatu hal yang dipandang biasa akan menimbulkan akibat-akibat yang sangat membahayakan kehidupan budaya dan politik pada taraf global dan transpersonal Mereka yang buta matematika pada umumnya akan mudah merasa jengkel dan terganggu apabila mereka berhadapan dengan manusia pemikir dan selalu tidak sabar menghadapinya dan kemudian menolak argumenargumen yang bersifat logis. Masyarakat yang membiarkan tumbuhnya kebutaan matematika dan ilmu pengetahuan akan selalu menolak argumen-argumen yang menuntut pemikiran rasional, sistematis dan tidak berpihak. Secara singkat kebutaan matematika dan ilmu pengetahuan alam yang melembaga akan membuat masyarakat kehilangan kemampuan untuk berfikir secara disipliner dalam menghadapi masalahmasalah nyata dari masalah-rnasalah yang relatif sepele, sampai pada masalah-masalah yang benar-benar gawat (Indra, 2009b).

Untuk dapat hidup dalam zaman modern tanpa menjadi bingung sangat dibutuhkan sejumlah pengetahuan tentang ilmu pengetahuan alam. Dalam hidup sehari-hari ketika berhubungan secara pribadi dengan produk teknologi baru, kita sebenarnya memerlukan penguasaan tentang sejumlah konsep dasar tentang sains dan teknologi. Kalau tidak, kita hanya menjadi budak dari peralatan teknologi yang serba modern itu. Sebagai contoh mungkin ada di antara kita yang terbiasa mengedarai mobil tanpa mempunyai gambaran tentang struktur mobil sebagai satu sistem. Akibatnya kalau ada suatu hal yang tidak beres dengan mobil yang dapat kita lakukan pergi ke bengkel. Begitu pula pemakai komputer banyak sekali yang tidak memahami perangkat keras dari komputer sebagai suatu sistem. Kalau terjadi gangguan lalu menjadi bingung. Contoh serta fakta itu memperlihatkan bahwa hidup dalam zaman modern dengan mempergunakan peralatan yang serba modern akan menjadi sangat membingungkan.

Untuk mengatasi kebutaan di bidang MIFA perlu dirumuskan kurikulum yang integratif yang bernuansa saintifik, dan juga kurikulum yang berbasis kompetensi untuk menopang kehidupan santri di masyarakat. Para ustadznya perlu ditingkatkan wawasannya dalam bidang MIFA agar memberi prespektif terhadap pelajaran agama yang diberikan ke santri, melalui pelatihan. Selain itu pada umumnya para ustadznya mengajar santri hanya dilandasi oleh keikhlasan semata, dan biasanya mengajar di banyak tempat dengan penghasilan yang sangat minim, untuk itu pemberian insentif oleh negara perlu ditingkatkan. Sarana dan prasarana pembelajaran juga sangat minim, banyak dari mereka yang belajar di tempat yang tidak layak. Bila pendidikan ini berjalan seadanya, maka jutaan anak didik sebagai produksnya hanya memiliki kualitas seadanya, 
mereka akan gamang menghadapi kehidupan yang semakin kompetitif ini, dan akhirnya peran mereka di masyarakat tidak berjalan optimal.

Di samping itu di pesantren salafiyah umumnya, hanya menanamkan nilai melalui sentuhan qalbu atau hati, dan kurang sentuhan kepada akal. Biasanya metode pembelajaran dengan sentuhan qalbu atau segi afektif adalah melalui kapalan. Pembelajarannya juga bersifat non-dialogis, karena sang ustadz hanya mendikte materi pelajaran, pemahaman santri tidak melalui analisis isi (Indra, 2016). Pendidikan pada era global ini tidak cukup lagi hanya dominan sentuhan qalbu tetapi juga sentuhan otak atau intelektual dan sangat efektif bila didukung dengan metode pembelajaran yang bersifat dialogis dan analisis. Melalui model pembelajaran seperti ini akan memunculkan santri yang berprakarsa dan memiliki kreatifitas, bukankah Allah Maha Pencipta/Maha Kreatif yang harus diambil semangatnya oleh pendidikan pesantren (QS. ali.Imran, 190, alMukminun, 12). Di samping itu pembelajaran pada masa kini juga harus lebih banyak pada sisi psikomotoriknya, karena setiap nilai harus diiringi dengan penerapannya. Sehingga para santri di samping banyak menguasai teori tetapi juga banyak aplikasinya. Sebagai contoh para santri kaya dengan teori-teori gramatikal bahasa Arab juga lancar dalam berkomuniksi; mereka menguasai teori tentang thaharah, berdasar hadis Nabi alnazhafa min al-iman/ kebersihan itu adalah sebagian dari iman langsung dapat diterapkan di lingkungannya (Indra, 2009b). Selain itu, para santri di era ini harus pula memiliki kecerdasan personal, sosial dan kemanusiaan. Fokusnya bukanlah semata kemampuan ritual dan keyakinan tauhid, melainkan juga akhlak sosial dan peran kemanusiaannya (Mulkan, 2001).

Saat ini Pesantren Salafiyah terus berkembang tetapi sangat gradual dan bersifat reaktif. Perubahan yang terbaik adalah mensyaratkan perencanaan dan kajian yang mendalam terhadap masa depan, kemana perkembangan dunia bergerak, kesanalah perubahan lembaga ini bergerak. Pendidikan Pesantren Salafiyah sistem belajarnya dapat menggunakan sistem pendidikan modern, belajar di kelas dan ada evaluasi terhadap pendidikan.

Selain itu, santri di pesantren Salafiyah mereka di samping menguasai skill beragama juga harus memiliki kehlian atau keterampilan hidup (life skill). Karena mereka akan hidup seperti manusia pada umumnya, mereka akan menjadi pemimpin formal di masyarakat, pedagang, petani, wirausaha dan lainnya; sementara mengandalkan skill beragama tidak memadai untuk menunjang kehidupan mereka. .

Untuk menopang hal-hal itu ke depan, ketersediaan media dan sumber belajar harus disempurnakan, seperti sarana dan prasarana pembelajaran yang memadai dengan gedungnya dan sarana perpustakaan lengkap diisi oleh buku agama, umum dan juga buku keterampilan dan pembelajaran bila perlu melalui alat teknologi dan mereka akan mengenal media itu dan mereka akhirnya tidak gagap teknologi (shock condition of tecknology) (Hamdy, 2004). Perlu pula di lembaga pendidikan ini disediakan bengkelbengkel keterampilan.

Selain itu Pesantren Salafiyah hendaklah dikelola dengan manajemen yang baik. Manajemen salah satu artinya adalah pengaturan (to manage), Allah telah 
mengisyaratkan dalam ayatnya: Yudabbbirul Amro minassamai fil ardh tsumma ya'ruju ilaihi bi yamin kaana miqdaruhu alfa sanatin mimma ta'uddun (QS. al-Sajdah, 5).artinya: "Dia mengatur urusan dari langit ke bumi, kemudian urusan itu naik kepadanya dalam satu hari yang kadarnya adalah seribu tahun menurut perhitunganmu". Kemudian, secara substansi salah satunya adalah membagi-bagi wewenang kepada yang lain, misalnya Allah memberi wewenang kepada makhluknya yang bernama malaikat untuk bertugas mencatat segala apa yang dilakukan oleh manusia baik atau buruk melalui malaikat Rakib dan Atid. Allah memberikan wewenang kepada malaikat Jibril untuk menyampaikan wahyu berupa ayat-ayat al-quran kepada Nabi Muhammad. Ketika Allah ingin menciptakan manusia Allah membuat perencanaan dengan mesdiskusikan dengan para malaikat dan iblis.

Selain itu salah satu pilar manajemen adalah seorang pemimpin, maka dalam khazanah Islam pemimpin adalah khalifah (QS. al-Baqarah, 30) atau raain (islamislogic.wordpress.com). Ayat yang menjelaskan tentang khalifah ini dalam surat alBaqarah yang artinya "manusia diciptakan untuk menjadi khalifah/pemimpin di dunia". Sedangkan kata raain, dalam hadis yang berbunyi bahwa "setiap orang adalah pemimpin nanti akan ditanya tentang kepemimpinannya".

Dalam sejarah Islam dapat ditelusuri dari perjalanan Nabi Muhammad SAW., dalam memimpin umat penuh dengan dedikasi atau totalitas. Di waktu malam ia mengadu kepada Allah agar banyak umat manusia menerima cahaya Islam dan mengadukan umatnya agar menjadi umat yang terbaik. Namun di siang hari ia dengan penuh totalitas memimpin di tengah umat bukan hanya sebagai orang yang memberi perintah tetapi ia langsung terlibat memberikan arahan kepada umat. Sebagai seorang Nabi ia menerima wahyu Allah SWT di kota Makkah untuk seluruh umat manusia dan di kota Madinah menerima wahyu untuk menyempurnakan wahyu-wahyu yang diterimanya di kota Makkah. Selama hidup di samping sebagai Nabi berfungsi sebagai pemimpin negara ia telah membuat undang-undang yang disebut dengan Piagam Madinah. Dalam kehidupannya sehari-hari sebagai pemimpin negara dan pemimpin umat ia memiliki sifat-sifat amanah dalam prespektif manajemen modern disebut dengan accountable. Ia bersifat tabligh dalam prespektif manajemen modern pengarahan, ia bersifat fathanah ia seorang yang mempunyai planing, dan controlling, dan ia bersifat siddiq, ia bersifat terbuka atau kepemimpinanya bersifat partisipatif (Saputra, 2011). Pemimpin yang langsung melihat dan melibatkan diri apa yang terjadi di tengah umatnya. Gambarangambaran tersebut menggambarkan berbagai fungsi manajemen seperti perencanaan, pengarahan dan pengawasan.

Sistem manajemen pendidikan yang profesional juga menjadi salah satu faktor penentu dalam memproduksi lulusan yang memiliki nilai kompetitif. Selama ini masih banyak Pesantren Salafiyah menerapkan pengelolaannya seadanya. Begitu pula distribusi wewenang tata kelola sangat tergantung pada komando kyai sebagai pemilik tunggal. Sehingga berbagai keputusan dari hal-hal yang bersifat strategis dan bahkan sampai hal-hal yang bersifat teknis harus dikonsultasikan terlebih dahulu kepada kyai. Sistem pengelolaannya belum terbagi dan belum otomatis berjalan secara distributif. 
Sebenarnya bila sistem pengelolaan tersebut telah terdistribusi dan terbagikan, ini akan meringankan beban kerja kyai, dan proses kaderisasi berjalan lebih cepat dan matang, yang nantinya menjadi kader penerus manakala kyai sudah sepuh atau telah wafat.

\section{Kesimpulan}

Saat ini Pesantren Salafiyah yang memiliki santri 1.800 .000 lebih tidak bisa menghindar dari berbagai fenomena globalisasi. Pengguna lembaga ini (user) adalah masyarakat yang hidup di era global, era dimana kemajuan IPTEK sangat luar biasa. Karena itu lembaga pendidikan ini harus berwawasan IPTEK dan mengakomodasi masalah-masalah global seperti adanya GATT, AFTA dan MEA. Untuk memenuhi hal itu para santri yang menjadikan Kitab-kitab Kuning sebagai rujukan utamanya yang bersisikan pemikiran-pemikiran Ibn Sina, ibn Rusyd dan lainnya yang berkaitan dengan ilmu kesehatan, biologi, astronomi, ekonomi yang juga telah dihargai di dunia Barat yang harus dipelajari oleh santri di pesantren, selain kitab fiqh, tauhid klasik dan lainnya. Untuk itu sarana-prasana pembelajaran perlu dipenuhi selain perpustakaan yang menyediakan kitab kitab klasik dan kontemporer serta buku-buku keterampilan. Santri setelah lulus di samping berpengetahuan agama dan non agama dan juga berketerampilan bila mungkin dikenalkan ke mereka dengan media teknologi pembelajaran sehingga mereka tidak gagap dengan hal itu, di samping memperbanyak pembelajaran menggunakan pendekatan psikomotorik dan juga menyiapkan mereka dengan keterampilan untuk hidupnya setelah menyelesaikan studinya.

Pesantren ini harus pula dikelola secara profesional oleh pemimpin yang terampil yang mengelola lembaga dengan amanah, fathanah, shiddik dan tabligh dan dengan azas transfaran dan akuntabilitas (Sulthon, 2004). Kelak pesantren akan menghasilkan santrisantri yang siap tampil berkompetisi di era globalisasi ini. Pemerintah harus pula memainkan perannya dengan bantuan dana dan fasilitas, juga sebagai fasilitator, motivator dan penjamin kualitasnya. Perannya harus fleksibel dengan memperhatikan budaya dan potensi yang ada di pesantren.

\section{DAFTAR PUSTAKa}

Abdullah, T. (Ed.). (1983). Agama dan Peradaban Sosial. Jakarta: Rajawali Pers.

Ahmad, A. S., \& Donnan, H. (1994). Islam Globalization and Postmodernity. London: Routledge.

Azra, A. (1998). Esei-esei Intelektual Muslim dan Pendidikan Islam. Jakarta: Logos.

Depag, T. (2000). Pola Pengembangan Madrasah Diniyah \& Pesantren. Depag, Jakarta.

Dhofier, Z. (1994). Tradisi Pesantren. Jakarta: LP3ES.

Dinamika Pesantren di Indonesia. (2003). Jakarta: Ditjen Bagais.

Faqih, M. (2003). Runtuhnya Teori Pembangunan dan Globalisasi. Yogyakarta: Insist Press. Faqih, M. (2006). Jalan Lain. Yogyakarta: Insist Press.

Fatah, R. A., Taufik, M. T., \& Bisri, A. M. (2005). Rekontruksi Pesantren Masa Depan. Jakarta: 
PT. Listafariska Putra.

Furchan, A. (2004). Transformasi Pendidikan Islam di Indonesia. Yogyakarta: Gama Media.

Hamdy, R. (2004). Meningkatkan Mutu Pendidikan MIPA di Pondok Pesantren. Makalah, disampaikan ke Ditjen Bagais.

Ibrahim, M. D. (1995). Teknologi, Emansipasi dan Transendensi. Bandung: Mizan.

Indra, H. (2002). Pesantren dan Masyarakat. Ikhlas, Majalah Depag, 23.

Indra, H. (2009a). Pendidikan Diniyah dan Globalisasi. Sosio-Religia, 8.

Indra, H. (2009b). Pesantren dan Peradaban Islam. Jabal Hikmah, STAIN Jayapura, 2.

Indra, H. (2016). Pendidikan Islam, Tantangan dan Peluang di Era Globalisasi. Yogyakarta: Deepublish.

Mas'ud, A. (1999). Pendidikan Islam dalam Era Reformasi dan Globalisasi. Religia, 2.

Moleong, L. J. (2001). Metodologi Penelitian Kualitatif. Bandung: Rosdakarya.

Mulkan, A. M. (2001). Humanisasi Pendidikan Islam. Afkar, 11.

Nata, A. (1999). Metodologi Studi Islam. Jakarta: Rajagrafindo.

Pendis, D. (2014). Statistik Pendidikan Islam 2012-2013. Jakarta.

Saputra, A. (2011). "Petunjuk Al-quran Dalam Memilih Pemimpin", diakses tanggal 13 Oktober.

Soejoeti, Z. (2002). Islamic Education,-- Academic orientation for the Degree of Doctor Honoris Causa di IAIN Syarif Hidayatullah. Jakarta, Jakarta: IAIN.

Sulthon, M. (2004). Management Pondok Pesantren. Yogyakarta: Lista Putra. 